\title{
Suitability of common models to estimate hydrology and diffuse water pollution in North-eastern German lowland catchments with intensive agricultural land use
}

\author{
Muhammad WASEEM (凶), Frauke KACHHOLZ, Jens TRÄNCKNER
}

Faculty of Agriculture and Environmental Sciences, University of Rostock, 18059 Rostock, Germany

\begin{abstract}
Various process-based models are extensively being used to analyze and forecast catchment hydrology and water quality. However, it is always important to select the appropriate hydrological and water quality modeling tools to predict and analyze the watershed and also consider their strengths and weaknesses. Different factors such as data availability, hydrological, hydraulic, and water quality processes and their desired level of complexity are crucial for selecting a plausible modeling tool. This review is focused on suitable model selection with a focus on desired hydrological, hydraulic and water quality processes (nitrogen fate and transport in surface, subsurface and groundwater bodies) by keeping in view the typical lowland catchments with intensive agricultural land use, higher groundwater tables, and decreased retention times due to the provision of artificial drainage. In this study, four different physically based, partially and fully distributed integrated water modeling tools, SWAT (soil and water assessment tool), SWIM (soil and water integrated model), HSPF (hydrological simulation program-FORTRAN) and a combination of tools from DHI (MIKE SHE coupled with MIKE 11 and ECO Lab), have been reviewed particularly for the Tollense River catchment located in North-eastern Germany. DHI combined tools and SWAT were more suitable for simulating the desired hydrological processes, but in the case of river hydraulics and water quality, the DHI family of tools has an edge due to their integrated coupling between MIKE SHE, MIKE 11 and ECO Lab. In case of SWAT, it needs to be coupled with another tool to model the hydraulics in the Tollense River as SWAT does not include backwater effects and provision of control structures. However, both SWAT and DHI tools are more data demanding in comparison to SWIM and HSPF. For studying nitrogen fate and transport in unsaturated, saturated, and river zone, HSPF was a better
\end{abstract}

Received August 6, 2018; accepted September 17, 2018

Correspondence: muhammad.waseem@uni-rostock.de model to simulate the desired nitrogen transformation and transport processes. However, for nitrogen dynamics and transformations in shallow streams, ECO Lab had an edge due its flexibility for inclusion of user-desired water quality parameters and processes. In the case of SWIM, most of the input data and governing equations are similar to SWAT but it does not include water bodies (ponds and lakes), wetlands and drainage systems. In this review, only the processes that were needed to simulate the Tollense River catchment were considered, however the resulted model selection criteria can be generalized to other lowland catchments in Australia, North-western Europe and North America with similar complexity.

Keywords diffuse pollution, ECO Lab, HSPF, lowland catchment, MIKE 11, MIKE SHE, modeling tools, SWAT, SWIM, Tollense River, water quality

\section{Introduction}

Water resources management requires constant monitoring of quality and quantity and proper assessment and management of watershed is the basis for conservation and rational utilization. Environmental policy decisions and successful management execution needs robust methods for assessing the hydrology and contribution of point and diffuse pollution sources to water quality problems, and also for assessing the estimated and achieved compliance with the desired watershed hydrology and water quality management objectives ${ }^{[1-3]}$. Surface, subsurface and groundwater quality is controlled by different key factors such as land use, water management and agricultural practices, diffuse and point emission sources, lithology, and geological structures of the aquifer ${ }^{[4-7]}$. Agriculture is the most prominent sector to affect the surface and subsurface water quality acting as a major diffuse water pollution source through the use of 
excessive amounts of fertilizers ${ }^{[8-10]}$. EU Water Framework Directive (WFD) aims to maintain a good ecological status in surface and groundwater bodies, and to prevent any further deterioration in the existing status of waters through hydrological and water quality management practices $^{[11,12]}$.

In Europe, agricultural diffuse water pollution is responsible for $50 \%$ to $80 \%$ of the total nitrogen load in surface water systems ${ }^{[13,14]}$. Use of fertilizer for agricultural production enhancement continues to negatively affect the overall water quality in Germany and especially in the lowlands due to their higher vulnerability to environmental pollution ${ }^{[15]}$. Lowlands are comparatively more exposed to environmental and socioeconomic hazards being an epicenter for agricultural production and related agricultural economic activities. In addition, the lack of topography increases their susceptibility to flooding, climate change, and deterioration of water quality resulting from low flow velocities and higher groundwater tables. Soil types in lowland catchments are usually organic soils, e.g., peatlands, bogs and fens. Due to high groundwater tables, lowland catchments are usually heavily regulated with the provision of drainage systems that result in eutrophication in rivers and lakes due to the reduction in water and nutrient retention times ${ }^{[16]}$. Decreased retention times means that the fertilizer applied to the crops/plants does not have sufficient time to be taken up by the plants or to decompose through denitrification, resulting in groundwater quality deterioration. Groundwater base flow, and more importantly the drainage flow, increases the nutrient concentrations in surface water bodies and causes higher algae growth and low oxygen levels in surface waters ${ }^{[17-19]}$. Tollense River has been taken as a representative of North-eastern German lowland catchments with all the hydrological, hydraulic and water quality processes in terms of nitrogen diffuse pollution in addition to particular lowland catchment characteristics such as backwater effect, control structures, pump flows, eutrophication, decreased retention times due to provision of drainage, high groundwater and higher inter and base flows.

\subsection{Tollense river catchment and water quality analysis}

The Tollense River is about $30 \mathrm{~km}$ long from its source, Tollense Lake, to its confluence with the Peene River at Demmin. Nutrient levels in the river and its tributaries are a concern for achieving a good chemical and ecological status. Within the framework of an ongoing German Government funded project (BOOT-Monitoring, a boatbased monitoring of water quality in the Tollense River), water quality is measured continually along a longitudinal section of the Tollense River from Klempenow to Demmin, with an approximate contributing catchment of about $300 \mathrm{~km}^{2}$ (Fig. 1). The catchment is mainly used for agriculture and is equipped with artificial drainage established during the $60 \mathrm{~s}$ and $70 \mathrm{~s}$. The current land use was estimated by the aerospace images obtained from the Rapid Eye Science Archive website. The study area consists of $2 \%$ water, $2 \%$ settlements, $18 \%$ forest, $75 \%$ arable land and pasture and 3\% miscellaneous. The initial results of the boat monitoring project have found nutrient concentrations higher than the permissible water quality limits according to the EU framework directive in different sections of the river, which predicts a strong correlation between base flow (saturated flow and drainage flow) and the Tollense River nutrient concentrations, as inflow of small water channels mainly fed by inter or drainage flow causes high nutrient concentrations in particular sections of the river. To understand the land use impacts and the fate and transport of nitrogen in the saturated, unsaturated and river zons, complete integrated hydrological and water quality modeling is necessary.

To quantify the inflow of nutrients, Gehmkow Augraben, a characteristic tributary of the Tollense River, was studied based on available monitoring data ${ }^{[20]}$. Twenty-five percent to $45 \%$ of the nutrient content in the Gehmkow Augraben derives from the base flow. Being heavily regulated, artificial drainage is a major contributor to the higher surface water nutrient concentrations

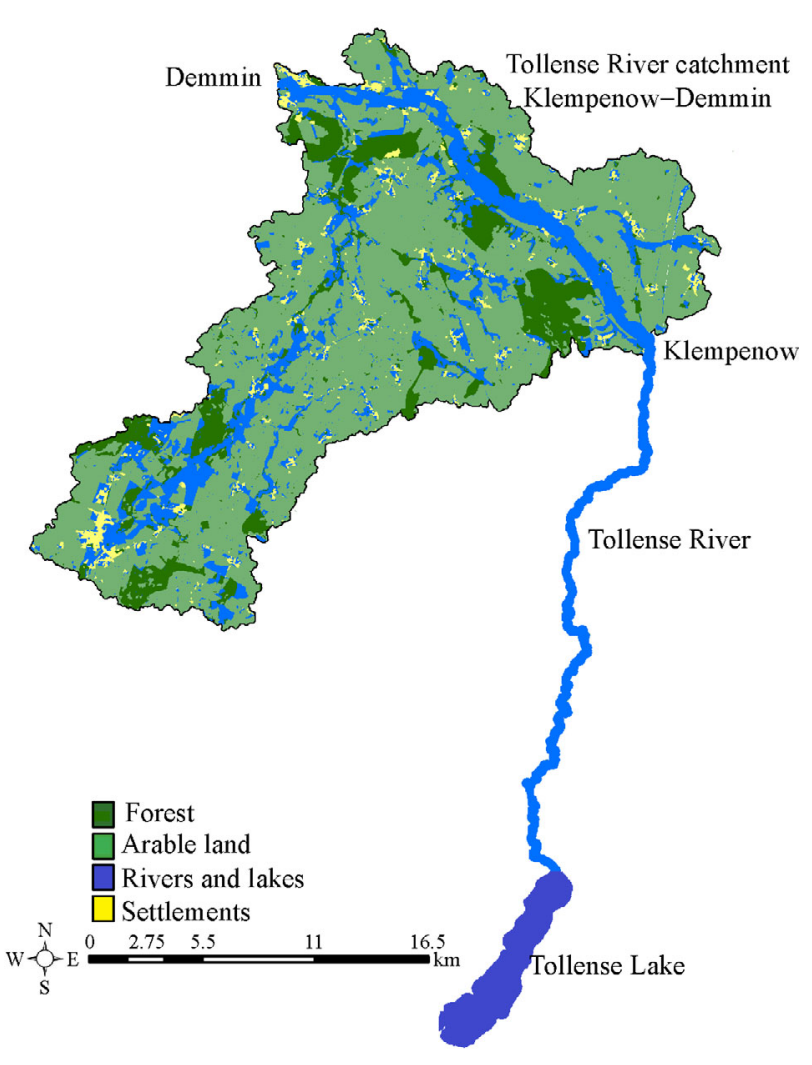

Fig. 1 Tollense area of investigation (Tollense River catchment from Klempenow to Demmin). Source: Rivers, lakes, and land use data was kindly provided by LUNG-MV (Landesamt für Umwelt, Naturschutz und Geologie Mecklenburg Vorpommern). 
due to decrease retention times. As a result, complete hydrological and water quality modeling is necessary to analyze and predict the hydrology and water quality in the whole Tollense River catchment. The current review study was conducted to find a suitable modeling tool to detect the sources of nutrient pollution and nitrogen dynamics in the Tollense River. Furthermore, it is necessary to quantify the land use impacts on the nutrients concentrations in the groundwater and then via groundwater and drainage flow in the Tollense River, as the available mass balances are insufficient to understand the dynamics and transport patterns of nutrients through surface and subsurface sources. Figure $2^{[20]}$ shows the overall water quality and nutrient concentrations in Gehmkow Augraben at the Lindenburg flow and surface water quality monitoring station.

To determine the water quality in the Tollense River catchment, a measurement program was conducted from January to December 2017 to measure the groundwater concentrations of nitrate, nitrite and ammonium. Twenty percent of the sampling stations showed higher nitrate concentration than the recommended limits of EU WFD. The collected data will be used for calibrating the modeling results, but it also raises the need for an integrated hydrological and water quality modeling in the area to determine the causes of higher nutrient concentrations in the groundwater. This review study focused mainly on the selection of an appropriate modeling tool to quantify the hydrology and water quality in lowland catchments and explains and compares different widely used integrated water modeling tools, their intended use, parameters and processes, limitations, strengths and their application to particular conditions. The selected models (described below) differ greatly in the degree of complexity in explaining the catchment spatially, temporally and also the complexity of their representation of the physical, chemical and biochemical processes involved in forecasting the fate and transport of nutrients in surface and subsurface waters. This report will allow researchers to make informed decisions when selecting a suitable model to predict hydrology and water quality in lowland catchments.

\subsection{Brief description of models}

Here the following four physically based, distributed modeling tools are briefly explained according to their advantages and disadvantages, and their ability to simulate the shallow rivers.

\subsubsection{Hydrological simulation program-FORTRAN (HSPF)}

HSPF is a semi-distributed, constant simulation model developed by HYDROCOMP, Inc. under a contract from the US Environmental Protection Agency in 1980 and until now the model was considered as one of the best simulating tools to model comprehensively watershed and water quality with a comparatively high level of flexibility ${ }^{[21-23]}$. HSPF has the ability to represent contributions of nutrients, sediment, pesticides, conservatives and faecal coliforms from agricultural areas, and to constantly simulate and predict water quality in pervious and impervious land surfaces, streams and in well-mixed

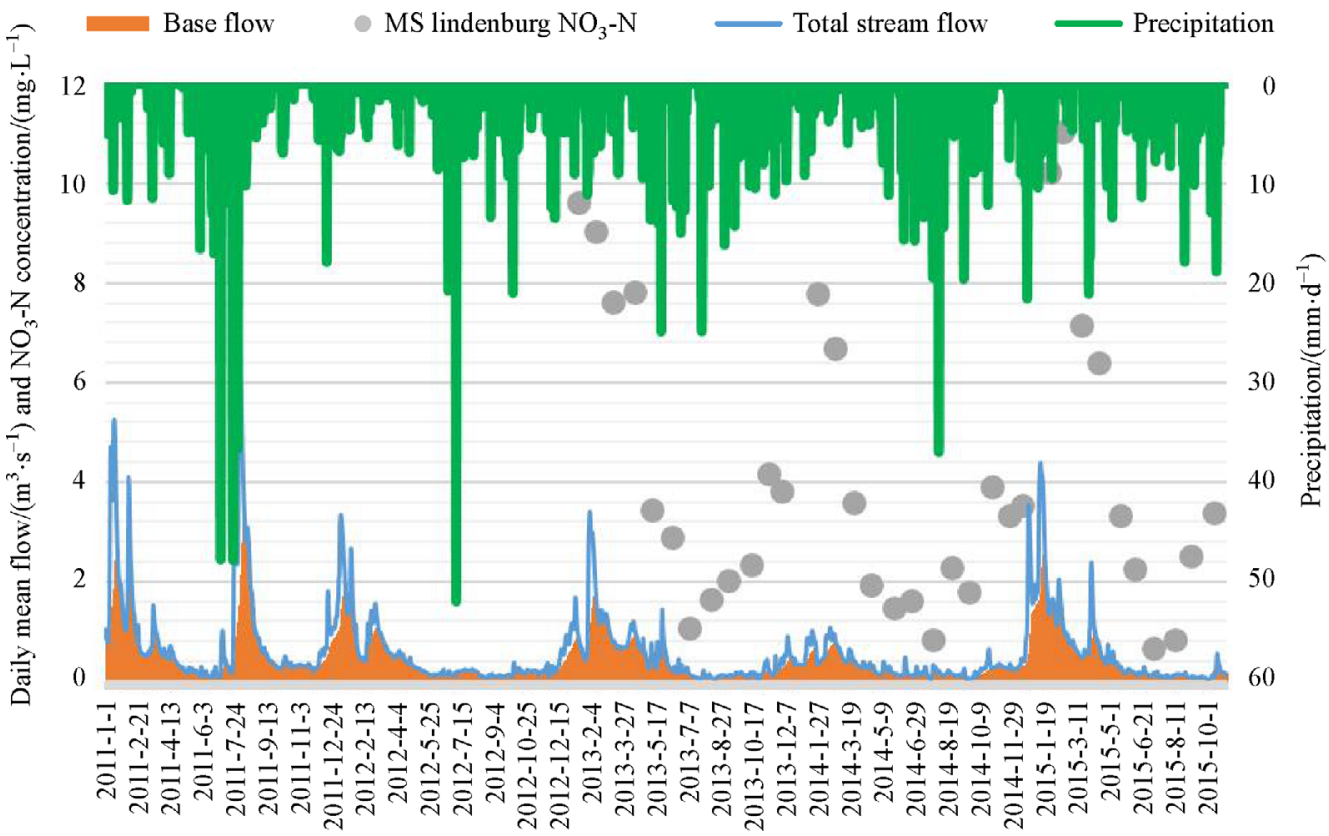

Fig. 2 Relationship between precipitation, measured surface and estimated base flow with $\mathrm{NO}_{3}-\mathrm{N}$ concentrations in Gehmkow Augraben at surface water quality monitoring station (MS) Lindenburg ${ }^{[20]}$ 
impoundments ${ }^{[21,24,25]}$. It is capable of simulating the water quality processes in a watershed by taking into account both diffuse and point sources of pollution ${ }^{[26,27]}$.

\subsubsection{Soil and water assessment tool (SWAT)}

SWAT developed by the US Department of Agriculture, is a continuous in time, physically based, distributed water quality model for the prediction of long-term effects of rural and agricultural practices on water quality in large composite watersheds with variable soils, land use and management practices ${ }^{[28,29]}$. SWAT is proficient in modeling a single catchment or a system of hydrologically connected subcatchments. The GIS based interface model, ArcSWAT, defines the river network and the point of catchment outflow, and the distribution of subcatchments and hydrological response units (HRU). HRUs comprise parts of each subcatchment with a distinctive mixture of land use, soil, topography and land management practices. This helps SWAT to model various parameters, including ET, erosion, plant growth, surface flow and water balance, for each subcatchment or HRU, which increases the precision of the simulation results ${ }^{[30]}$. SWAT daily water balance takes into account actual evapotranspiration, plant transpiration, canopy interception, surface runoff, soil evaporation, and vertical water movement in the unsaturated soil zone to the aquifer ${ }^{[31]}$. For nitrogen transformation and transport, SWAT takes into account both point and diffuse sources of emissions (fertilizer applications as diffuse sources and outflow from wastewater treatment plants as point sources in the case of the Tollense River catchment $)^{[32,33]}$. SWAT simulates the nitrogen cycle and losses to the river network in various forms (dissolved and particulate) through surface runoff, sediment, tile drainage and aquifer ${ }^{[31]}$.

\subsubsection{Soil and water integrated model (SWIM)}

SWIM is a time continuous, spatially semi-distributed model with an ability to simulate integrated hydrological processes, nutrient cycle, vegetation growth and sediment transport at the catchment scale. The system includes in addition, the interface to the geographic information system GRASS (geographic resources analysis support system $)^{[34]}$, which provides the freedom to extract spatially distributed parameters of land use, soil, elevation, hydrotope and routing structure for the basin under consideration $^{[35]}$. Model objectives include a comprehensive GIS based tool for the coupled hydrological and water quality simulation in large scale watersheds ranging from 100 to $10000 \mathrm{~km}^{2}$. Climate change and land use impacts on hydrological processes, agricultural food production and water quality deterioration at a regional scale can be simulated and analyzed with SWIM ${ }^{[36]}$.

\subsubsection{DHI tools (MIKE SHE, MIKE 11 and ECO Lab)}

MIKE $\mathrm{SHE}^{[37]}$ is a physically based, fully distributed modeling system capable of analyzing all major processes in the land phase of the hydrologic cycle. MIKE SHE simulates all the processes in the hydrological cycle by fully integrating the surface, subsurface and groundwater flow ${ }^{[38-40]}$. MIKE 11 is a hydraulic river model capable of simulating potential hydrology and flood risks. Moving from hydraulic model to water quality model, the upper boundary simulates water temperatures, by allowing heat balance and wind options within the hydrodynamic module. This allows use of comprehensive heat calculations, which consider humidity, air temperature, sunshine hours and wind speed to model and predict water temperatures alongside the river. The advection-dispersion module determines the movement of water quality in the system through advection and dispersion processes. The ECO Lab water quality module simulates the biogeochemical cycling of water quality factors. ECO Lab module contains a number of standard templates, comprising different combinations of water quality determinants and processes, including water temperature, salinity, dissolved oxygen, biochemical oxygen demand, ammonia, nitrate and orthophosphate. In overall, ECO Lab needs a large amount of data and it is difficult to simulate the determinants without having sufficient amount of data ${ }^{[41]}$.

\section{Materials and methods}

This study focused on the selection of a suitable modeling tool and the model selection framework was based on (1) desired hydrological and hydraulic processes, (2) specific characteristics of hydrological and water quality models (governing equations, and spatial and temporal resolution, (3) data availability, and (4) ability to model the fate and transport of nitrogen in surface, subsurface and saturated water zones.

\subsection{Hydrological and hydraulic processes}

Desired hydrological and hydraulic processes simulated by a model are the key arguments to determine whether the model has the ability to predict the required results. Desired hydrological processes in the case of the Tollense River catchment require precipitation, interception, evapotranspiration, infiltration, and transport of nutrient through surface and subsurface flow. In case of hydraulics, the Tollense River has a problem of backwater effects from the Peene River in the periods with low flow in the Tollense. The Tollense River is equipped with three broad-crested weirs with gates, so it also needs a control strategy to operate the gates in periods of high and low flows. All the 
models included in this study are physically-based distributed models, and can simulate the watershed. Figure 3 and Table 1 below shows the desired hydrological and hydraulic processes and the ability of different selected models to simulate the desired processes in a lowland catchment.

The channel flow calculation can be realized by coupling the hydrological model to a hydrodynamic model. The reason why hydrological models are not used for simulating open channel flow is that their use of simple flow routing methods, which concentrate only on flood wave delays and attenuation such as the linear reservoir model $^{[42]}$ and Muskingum method ${ }^{[43]}$. That means the desired hydraulic processes, such as backwater effect, operation of control structures and pump operations cannot be taken into account. 1D hydraulic models simplify the river channel into a number of cross sections perpendicular to the channel centerline, and the floodplain is viewed as an extended cross section. These models can provide a good explanation of flood routing for in-bank flows and are extensively in practice. Examples of well-known 1D hydraulic modeling systems include ISIS $^{[44]}$, MIKE11 ${ }^{[45]}$ and HEC-RAS ${ }^{[46]}$. Due to simplification, 1D models are incapable of precisely reproducing floodplain inundations and flows over complex topography. 3D hydraulic models, such as FLUENT ${ }^{[47]}$ and MIKE $3^{[48]}$, involve full representations of flow processes in three-dimensions. These models may potentially provide improved representation of the physical flow processes and hence more precise results, but they are also computationally challenging due to the complex model structures. Unlike hydraulic models based on kinematic wave equations, hydraulic models using diffusive, dynamic or inertial wave equations can handle backwater effects. These models can be coupled with defined hydrological models but will require data preparation tools to modify the hydrological model's output accordingly. Internal coupling has also been reported in the literature ${ }^{[49]}$, and the governing equations for hydraulic models and hydrological models can be solved separately, with information at the shared

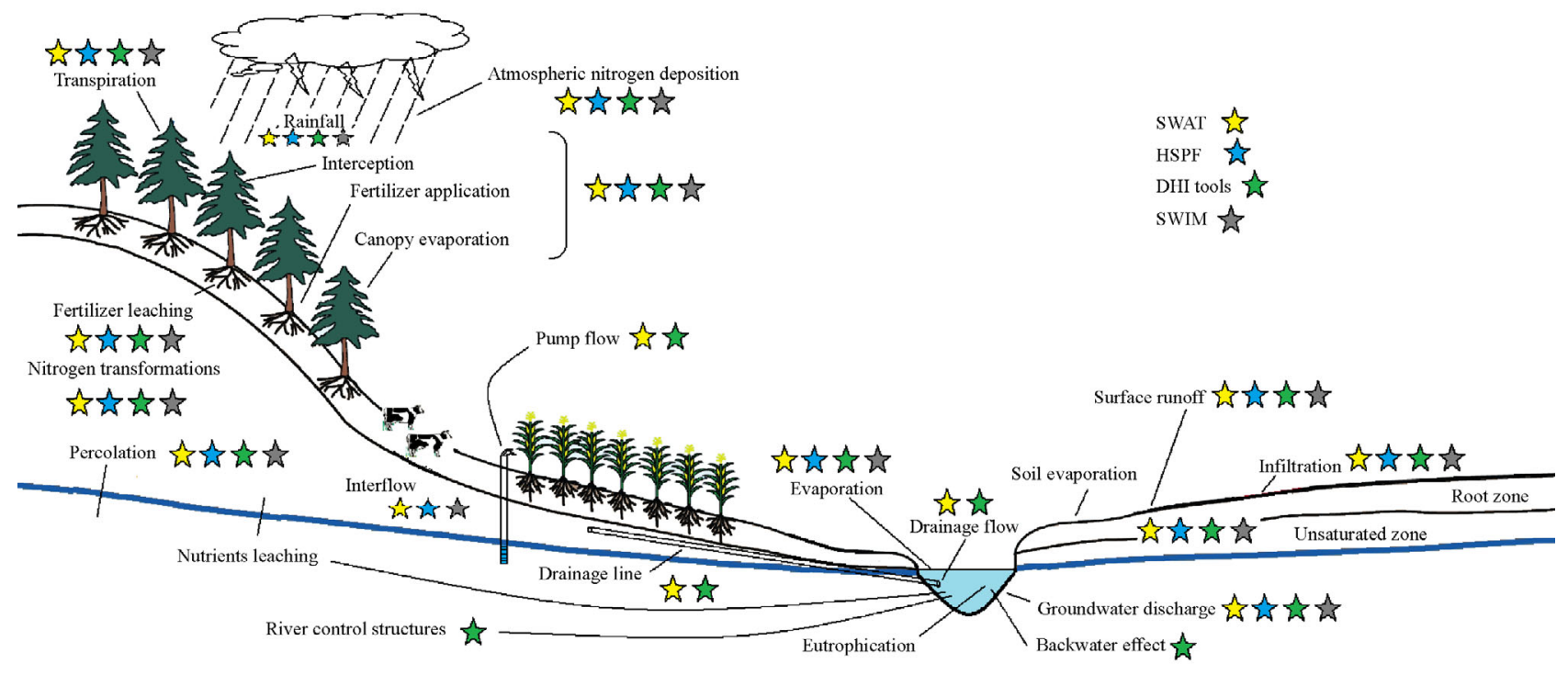

Fig. 3 Desired hydrological and hydraulic processes in the study area of the Tollense River catchment

Table 1 Ability to model the desired hydrological processes by selected modeling tools

\begin{tabular}{lccc}
\hline \multirow{2}{*}{ Desired hydrological processes } & \multicolumn{2}{c}{ Relevant models } \\
\cline { 2 - 4 } Surface runoff & SWAT & HSPF & MIKE SHE \\
Evapotranspiration & $\bullet$ & $\bullet$ & $\bullet$ \\
Infiltration & $\bullet$ & $\bullet$ & $\bullet$ \\
Interflow & $\bullet$ & $\bullet$ & $\bullet$ \\
Base flow & $\bullet$ & $\bullet$ & $\bullet$ \\
Pump flow & $\bullet$ & & $\bullet$ \\
Drainage & $\bullet$ & & $\bullet$ \\
Urban drainage & $\bullet$ & $\bullet$ \\
\hline
\end{tabular}


boundaries updated and exchanged at each computational time $\operatorname{step}^{[50]}$.

\subsection{Specific characteristics of hydrological and water quality models}

Governing equations, spatial and temporal resolutions are elementary to all the hydrologic models and these affect the performance and applicability of a model. In physically-based models, mass transfer, momentum and energy are analyzed using normally Saint-Venant equations for surface flow, Richards equation for unsaturated flow, an empirical Kristensen and Jensen method for evapotranspiration and Darcy equation for groundwater flow calculations and are solved by various numerical methods. Saint-Venant equations or dynamic wave equations which consist of continuity and momentum for gradually varied unsteady flow, require much computing time and are not often used in catchment modeling. Diffusive and kinematic wave equations are used in many surface runoff routing models. In diffusive wave equations, continuity equations and momentum equations ignoring dynamic terms (local and convective accelerations) are used while in kinematic wave equations, the momentum equation is approximated by ignoring all the acceleration and pressure gradient terms of the dynamic momentum equation (i.e., energy gradient is equal to bed slope). DHI tool (MIKE SHE) uses diffusive wave equations and finite difference approximation for their solutions. SWAT uses the Soil Conservation Service runoff curve number method to compute runoff volumes and other empirical relations to compute peak flows ${ }^{[38,51]}$. The transfer of parameter sets over different temporal and spatial resolutions is usual practice in many large-scale modeling hydrological studies. The amount to which parameters are transferable across temporal and spatial resolutions is also a key factor for understanding how well spatial and temporal variability is simulated in the models ${ }^{[52]}$. Table 2 shows the strength of models on the basis of their resolution (spatial and temporal) and applied governing equations.

\subsection{Input data requirement}

Input data required to run a model is another important criterion for the selection and application of any hydrologic and water quality model. Lack of required data are a major constraint, especially in the developing world, for successful application of a model. The MIKE SHE and the SWAT model require extensive data but can be managed with readily available data sets from various public sources, as in case of the Tollense, most of the hydrological and water quality data was provided by LUNG-MV (Landesamt für Umwelt, Naturschutz und Geologie Mecklenburg Vorpommern) and StÄLU (Staatliche Ämter für Landwirtschaft und Umwelt Mecklenburg Vorpommern). Climate data was collected from DWD

Table 2 Governing equations, spatial and temporal resolution of selected modeling tools

\begin{tabular}{|c|c|}
\hline Resolution & Governing equation \\
\hline $\begin{array}{l}\text { SWAT } \\
\text { Spatial: flexible, } \\
\text { Temporal: continuous } \\
\end{array}$ & $\begin{array}{l}\text { - Runoff volume (Modified SCS-curve number or G\&A infiltration method) } \\
\text { - Peak runoff rate (modified rational formula or the SCS TR-55 method) } \\
\text { - Lateral subsurface flow and percolation (kinematic storage routine) })^{[54]} \\
\text { - Potential evapotranspiration (Hargreaves, Priestley-Taylor and Penman-Monteith equations) } \\
\text { - Sediment yield (modified universal soil loss equation) } \\
\text { - Water routing (variable storage coefficient method or Muskingum routing method and Manning's equation to } \\
\text { define flow) }\end{array}$ \\
\hline $\begin{array}{l}\text { HSPF } \\
\text { Spatial: flexible, } \\
\text { Temporal: flexible or user-defined } \\
\text { time step }^{[53]}\end{array}$ & $\begin{array}{l}\text { - HSPF uses basic continuity to model water flow through the channel }{ }^{[55]} \text { (otherwise known as storage routing or } \\
\text { kinematic wave) }\end{array}$ \\
\hline $\begin{array}{l}\text { SWIM } \\
\text { Spatial: flexible, } \\
\text { Temporal: daily }{ }^{[56]}\end{array}$ & $\begin{array}{l}\text { - Surface runoff volume (modified SCS-curve number technique) } \\
\text { - Peak runoff rate (modified rational formula) } \\
\text { - Storage routing technique }{ }^{[57]} \\
\text { - Lateral subsurface flow kinematic storage routine }{ }^{[54]} \\
\text { - Potential evapotranspiration } \\
\text { - Soil evaporation and plant transpiration }{ }^{[59]} \\
\text { - Groundwater flow }{ }^{[60]} \\
\text { - Transmission } \operatorname{losses}^{[61]}\end{array}$ \\
\hline $\begin{array}{l}\text { MIKE SHE } \\
\text { Spatial: flexible, } \\
\text { Temporal: event based \& } \text { continuous }^{[38]}\end{array}$ & $\begin{array}{l}\text { - Runoff on overland (2D diffusive wave equations) } \\
\text { - Runoff in channels (1D diffusive wave equations solved by implicit fine-difference method) } \\
\text { - Vertical flow (Richards equations) } \\
\text { - Actual evapotranspiration }{ }^{[62]} \\
\text { - Subsurface flow (3D groundwater flow equations solved using numerical finite-difference method and simulated } \\
\text { river ground water exchange) } \\
\text { - Chemical simulations (numerically solved advection-dispersion equation) }\end{array}$ \\
\hline
\end{tabular}


(Deutsche Wetterdienst), German Weather Services Department. On average, MIKE SHE and SWAT have extensive input data requirement, while HSPF and SWIM require least input data to run the model shown in Table 3.

\subsection{Nitrogen dynamics}

For the simulation of nutrient fate, additional input data are required to characterize the system. The major forms of $\mathrm{N}$ inputs described in models are organic $\mathrm{N}$, fresh organic $\mathrm{N}$, active organic $\mathrm{N}$, dissolved $\mathrm{N}, \mathrm{NO}_{3}^{-}, \mathrm{NO}_{2}^{-}, \mathrm{NH}_{4}^{+}, \mathrm{NH}_{3}$, and total $\mathrm{N}$. The sources of $\mathrm{N}$ inputs shown in Table 4 are mainly soil, groundwater, surface water bodies, plant uptake, urban source, point source, fertilizer and atmosphere.

\section{Results and discussion}

It is expected that the simpler the model the more imprecise the understanding. Therefore, basic models could be used for the initial characterization of a surface water body. As more reliable data are available, a more refined and improved model could be used. Therefore, during the selection of the model the key issue is the availability of data for the key parameters in time and space. However, it should also be acknowledged that more complicated models do not necessarily result in more accurate understanding of the processes being described. A prudent approach is to start with a basic model and gradually move to more detailed and comprehensive model. Data requirement is usually an important aspect in selecting a model. All four models have the tendency to model the catchment

Table 3 Input data required by the selected hydrological and water quality models ${ }^{[22,23,37,38,53-55,63-67]}$

\begin{tabular}{|c|c|c|}
\hline Tool & Category & Parameters \\
\hline \multirow[t]{5}{*}{ SWAT } & Climate (6) & $\begin{array}{l}\text { Rainfall, air temperature, solar radiation, wind speed, evapotranspiration and } \\
\text { humidity/dew point }\end{array}$ \\
\hline & Hydrology and hydrogeology (7) & $\begin{array}{l}\text { Water table height, hydraulic conductivity, groundwater extraction, initial shallow } \\
\text { aquifer storage, recharge water, drain spacing, and irrigation }\end{array}$ \\
\hline & Soil data (7) & $\begin{array}{l}\text { Layer thickness, bulk density, initial soil water content, field capacity", wilting point", } \\
\text { hydraulic conductivity, and porosity }\end{array}$ \\
\hline & Land use and vegetation (7) & $\begin{array}{l}\text { Land use, vegetation type, vegetation height, leaf area index, root depth, fertilizing } \\
\text { rate, and crop management }\end{array}$ \\
\hline & Topography (6) & $\begin{array}{l}\text { Area, elevation, land surface slope length, land surface slope steepness, hill slope } \\
\text { length, and hill slope steepness }\end{array}$ \\
\hline \multirow[t]{5}{*}{ MIKE SHE } & Climate (5) & Rainfall, air temperature, solar radiation, wind speed, and grass reference evaporation \\
\hline & Hydrology and hydrogeology (9) & $\begin{array}{l}\text { Water table height, hydraulic conductivity ( } x \text {-, } y \text {-and } z \text {-directions), specific yield, } \\
\text { specific storage, groundwater extraction, initial shallow aquifer storage, recharge } \\
\text { water, drain spacing, and irrigation }\end{array}$ \\
\hline & Soil data (6) & $\begin{array}{l}\text { Layer thickness, bulk density, initial soil water content, field capacity, wilting point, } \\
\text { and hydraulic conductivity }\end{array}$ \\
\hline & Land use and vegetation (5) & Land use, vegetation type, leaf area index, root depth, and fertilizer application rates \\
\hline & Topography (1) & Digital elevation model \\
\hline \multirow[t]{5}{*}{ HSPF } & Climate (6) & $\begin{array}{l}\text { Rainfall, air temperature, solar radiation, wind speed, evapotranspiration, and } \\
\text { humidity/dew point }\end{array}$ \\
\hline & Hydrology and hydrogeology (3) & Active groundwater storage, interflow storage, and lower zone storage \\
\hline & Soil data (3) & Layer thickness, bulk density, and initial soil water content \\
\hline & Land use and vegetation (2) & Land use, and vegetation type \\
\hline & Topography (4) & Area, elevation, land surface slope length, land surface slope steepness \\
\hline \multirow[t]{5}{*}{ SWIM } & Climate (6) & $\begin{array}{l}\text { Rainfall, air temperature, solar radiation, wind speed, evapotranspiration, and } \\
\text { humidity/dew point }\end{array}$ \\
\hline & Hydrology and hydrogeology (6) & $\begin{array}{l}\text { Water table height, hydraulic conductivity, specific yield, groundwater extraction, } \\
\text { drain spacing, Irrigation }\end{array}$ \\
\hline & Soil data (7) & $\begin{array}{l}\text { Layer thickness, bulk density, initial soil water content, field capacity, wilting point, } \\
\text { hydraulic conductivity, and porosity }\end{array}$ \\
\hline & Land use and vegetation (5) & Land use, vegetation type, leaf area index, root depth, and fertilizer application rates \\
\hline & Topography (7) & $\begin{array}{l}\text { Area, elevation, land surface slope length, land surface slope steepness, hill slope } \\
\text { length, hill slope steepness, and hill slope width }\end{array}$ \\
\hline
\end{tabular}

Note: "Provided as input or calculated by the model. 
Table 4 Input required for predicting nitrogen transformations and transport in surface and subsurface water ${ }^{[39,53-55,62-67]}$

\begin{tabular}{|c|c|c|c|c|}
\hline \multirow{2}{*}{ Item } & \multicolumn{4}{|c|}{ Relevant models } \\
\hline & SWAT & SWIM & ECO Lab $^{*}$ & HSPF \\
\hline \multicolumn{5}{|l|}{ Initial soil nitrogen } \\
\hline Organic N & $\bullet$ & $\bullet$ & - & $\bullet$ \\
\hline $\mathrm{NO}_{3}^{-}$ & $\bullet$ & $\bullet$ & $\bullet$ & $\bullet$ \\
\hline $\mathrm{NH}_{4}^{+}$ & & $\bullet$ & & $\bullet$ \\
\hline \multicolumn{5}{|l|}{ Point sources } \\
\hline Organic N & $\bullet$ & & $\bullet$ & \\
\hline $\mathrm{NO}_{3}^{-}$ & $\bullet$ & & - & \\
\hline $\mathrm{NO}_{2}^{-}$ & $\bullet$ & & $\bullet$ & \\
\hline $\mathrm{NH}_{4}^{+}$ & $\bullet$ & & $\bullet$ & \\
\hline \multicolumn{5}{|c|}{ Fertilizer nitrogen (crop-specific) } \\
\hline Organic N & $\bullet$ & & $\bullet$ & \\
\hline Active organic $\mathrm{N}$ & & $\bullet$ & $\bullet$ & \\
\hline Inorganic $\mathrm{N}$ & $\bullet$ & & $\bullet$ & \\
\hline $\mathrm{NH}_{4}^{+}$ & $\bullet$ & & $\bullet$ & \\
\hline \multicolumn{5}{|l|}{ In-stream nitrogen } \\
\hline Organic N & $\bullet$ & & $\bullet$ & \\
\hline $\mathrm{NO}_{3}^{-}$ & $\bullet$ & & $\bullet$ & $\bullet$ \\
\hline $\mathrm{NO}_{2}^{-}$ & $\bullet$ & & $\bullet$ & $\bullet$ \\
\hline $\mathrm{NH}_{4}^{+}$ & $\bullet$ & & $\bullet$ & \\
\hline \multicolumn{5}{|c|}{ Atmospheric deposition } \\
\hline $\mathrm{NO}_{3}^{-}$in rain & $\bullet$ & $\bullet$ & & \\
\hline $\mathrm{NH}_{4}^{+}$in rain & $\bullet$ & & & \\
\hline
\end{tabular}

Note: "ECO Lab is not a model, but a module that works in combination with MIKE SHE and MIKE 11 model to simulate the nitrogen fate and transport in groundwater and in surface water.

on average, but in terms of hydrological processes SWAT and MIKE SHE demand more data in comparison to HSPF and SWIM, but at the same time can take into account all the desired hydrological processes including pump flow and drainage, not included by HSPF and SWIM. In case of topography in MIKE SHE, the parameters needed are less than the other models due to the fact that it takes a digital elevation model as an input to simulate the topography, while in case of SWIM, the higher number of topographical input parameters needed makes it more data demanding. In case of SWIM, most of the input data and governing equations are similar to SWAT but it does not include water bodies (ponds and lakes), wetlands and drainage system. In terms of hydraulic processes, none of the selected hydrological models have the ability to simulate the hydraulic processes involved in the Tollense River basin. All these models need to be coupled with another model to analyze and predict the backwater effect and control strategy for operation of weirs and gates. Here MIKE SHE is considered good, being a component of the DHI software family, as it can be coupled with MIKE 11, which can simulate backwater effect, pump flows, river gates and weir operations. Figure 4 shows the input data requirements of the models.

For $\mathrm{N}$ transport and transformations, ECO Lab and HSPF are better and include the $\mathrm{N}$ cycle in comparison to SWIM and SWAT. A problem in using SWAT for nitrogen transformation is the use of only built-in parameters and new parameters cannot be included. MIKE SHE has a shell or module called ECO Lab which has the tendency to model the nitrogen transformations in the river and desired parameters can be added accordingly. SWAT and SWIM do not have the ability to simulate the soil nitrogen and in terms of interflow which is a considerable part in case of the Tollense River basin. SWAT and SWIM can only model $\mathrm{NO}_{3}^{-}$, while ECO Lab and HSPF can predict both $\mathrm{NO}_{3}^{-}$and $\mathrm{NH}_{4}^{+}$in interflow. Interflow inorganic $\mathrm{N}$, however, can only be simulated with ECO Lab. The case of groundwater flow follows the same pattern, with SWIM and SWAT only predicting $\mathrm{NO}_{3}^{-}$, while ECO Lab can predict $\mathrm{NO}_{3}^{-}, \mathrm{NH}_{4}^{+}$and dissolved $\mathrm{N}$, whereas HSPF can only predict the first two. Nitrification, denitrification and 


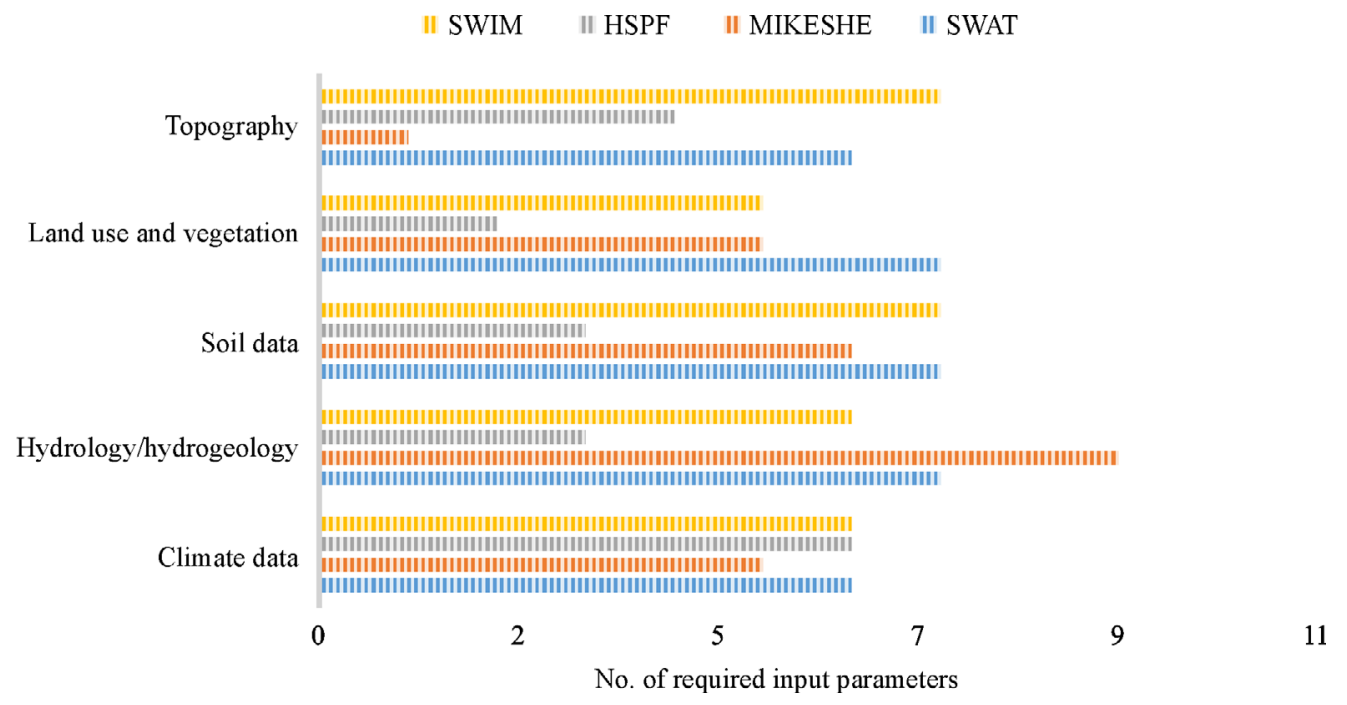

Fig. 4 Summary of minimum input parameters required by the selected models

decomposition can be handled by all tools. For plant $\mathrm{N}$ but can model $\mathrm{NO}_{3}^{-}, \mathrm{NH}_{4}^{+}$, and $\mathrm{ECO}$ Lab can handle all uptake, SWAT and SWIM can only simulate inorganic N three parameters. These differences are summarized in taken up by plants, whereas, HSPF cannot model inorganic Table 5.

Table 5 Prediction of nitrogen transformations and transport in surface and subsurface waters by the selected models ${ }^{[59-62]}$

\begin{tabular}{|c|c|c|c|c|}
\hline \multirow{2}{*}{ Item } & \multicolumn{4}{|c|}{ Relevant models } \\
\hline & SWAT & SWIM & ECO Lab & HSPF \\
\hline \multicolumn{5}{|l|}{ Soil nitrogen } \\
\hline Organic $\mathrm{N}$ & & & $\bullet$ & $\bullet$ \\
\hline $\mathrm{NO}_{3}^{-}$ & & & $\bullet$ & $\bullet$ \\
\hline $\mathrm{NH}_{4}^{+}$ & & & $\bullet$ & $\bullet$ \\
\hline \multicolumn{5}{|c|}{ Transport through surface runoff } \\
\hline $\mathrm{NO}_{3}^{-}$in water & $\bullet$ & $\bullet$ & $\bullet$ & $\bullet$ \\
\hline $\mathrm{NH}_{4}^{+}$in water & & & $\bullet$ & $\bullet$ \\
\hline \multicolumn{5}{|l|}{ Transport through interflow } \\
\hline $\mathrm{NO}_{3}^{-}$ & $\bullet$ & $\bullet$ & $\bullet$ & $\bullet$ \\
\hline $\mathrm{NH}_{4}^{+}$ & & & $\bullet$ & $\bullet$ \\
\hline Inorganic $\mathrm{N}$ & & & $\bullet$ & \\
\hline \multicolumn{5}{|c|}{ Transport through subsurface drainage flow } \\
\hline Inorganic $\mathrm{N}$ & & & $\bullet$ & \\
\hline \multicolumn{5}{|c|}{ Transport through groundwater flow } \\
\hline $\mathrm{NO}_{3}^{-}$ & $\bullet$ & & $\bullet$ & $\bullet$ \\
\hline $\mathrm{NH}_{4}^{+}$ & & & $\bullet$ & $\bullet$ \\
\hline \multicolumn{5}{|l|}{ Transformation } \\
\hline Fixation & $\bullet$ & & $\bullet$ & \\
\hline Nitrification & $\bullet$ & & $\bullet$ & $\bullet$ \\
\hline Ammonia volatilization & $\bullet$ & & $\bullet$ & $\bullet$ \\
\hline Denitrification & $\bullet$ & SWIM & $\bullet$ & $\bullet$ \\
\hline \multicolumn{5}{|l|}{ Adsorption and desorption } \\
\hline Total N & $\bullet$ & & & $\bullet$ \\
\hline
\end{tabular}


Table 6 Openness, availability of graphical user interface and online support for selected models ${ }^{[53-67]}$

\begin{tabular}{|c|c|c|c|c|}
\hline Item & SWAT & HSPF & SWIM & DHI tools \\
\hline Model type & $\begin{array}{l}\text { Physically based and } \\
\text { distributed }\end{array}$ & Physically based and distributed & $\begin{array}{l}\text { Physically based and } \\
\text { semi-distributed }\end{array}$ & $\begin{array}{l}\text { Physically based and } \\
\text { distributed }\end{array}$ \\
\hline $\begin{array}{l}\text { Flexibility to grid } \\
\text { structure }\end{array}$ & $\begin{array}{l}\text { Sub-basin structure but } \\
\text { can be operated on grids }\end{array}$ & $\begin{array}{l}\text { Sub-basin structure but can be } \\
\text { operated on grids }\end{array}$ & $\begin{array}{l}\text { Sub-basin structure but can be } \\
\text { operated on grids }\end{array}$ & Flexible \\
\hline $\begin{array}{l}\text { Flexibility in } \\
\text { resolution }\end{array}$ & $\begin{array}{l}\text { Depends on the definition } \\
\text { of sub-basins }\end{array}$ & $\begin{array}{l}\text { Depends on the definition of } \\
\text { sub-basin }\end{array}$ & $\begin{array}{l}\text { Depends on the definition of } \\
\text { sub-basins and hydrotopes }\end{array}$ & Flexible \\
\hline $\begin{array}{l}\text { Possibility of } \\
\text { calibration }\end{array}$ & Automatic and manual & Tools available & Tools available & Automatic and manual \\
\hline Tools availability & $\begin{array}{l}\text { SWAT (The Soil \& Water } \\
\text { Assessment Tool) website, } \\
\text { TAMU, USA }\end{array}$ & $\begin{array}{l}\text { EPA (United States Environmental } \\
\text { Protection Agency) website, USA }\end{array}$ & $\begin{array}{l}\text { Potsdam Institute for Climate } \\
\text { Impact Research, Potsdam, } \\
\text { Germany }\end{array}$ & $\begin{array}{l}\text { MIKE powered by DHI, } \\
\text { Denmark }\end{array}$ \\
\hline License agreement & Open source & Open & Provided on request & License required \\
\hline
\end{tabular}

Model openness, availability of graphical user interface and online support are other important considerations in selecting the appropriate model and depend also on the available budget for a particular study. Table 6 details these aspects of the models and their origins with their license requirements.

\section{Conclusions}

The models were designed and verified for a specific area and were built around the data currently available to the developers, so different hydrological conditions and unavailability of the required input data will limit the use of certain modeling tools. In addition, for more complex models, the data requirements are often so high that it is difficult to collect all the required data, especially when the model is to be applied to a large area. This review was focused on the desired objective of modeling the nitrogen dynamics in lowland catchments by considering the hydrological, hydraulic and water quality processes. This study aimed to be objective, and does not declare any judgment about good or bad modeling tools, but rather made comparisons based on multi criteria analysis. In this review, Tollense River catchment was considered as a characteristic example of north-eastern lowland catchments and special lowland catchment characteristics served as a representative for selecting a suitable modeling tool. DHI tools and SWAT are able to model the desired hydrological processes in detail, but in case of hydraulic processes, DHI tools have an edge over SWAT due to their integrated coupling within the DHI tools as SWAT needs coupling with other modeling tools to handle the hydraulic processes. For nitrogen fate and transport in unsaturated, saturated, and river zones, HSPF is a better model to simulate the desired nitrogen transformation and transport processes, while in the case of nitrogen dynamics and transformations in shallow streams, ECO Lab has an edge due its openness for inclusion of user-desired water quality parameters and processes. However, for lowland catchments, where integrated modeling is required to determine the impacts of land use on surface and subsurface water and the nitrogen dynamics in a river, DHI tools are a good compromise. Overall, open source tools such as SWAT are preferable due to large number of users, available literature and platforms for sharing problems and issues. This review focused on north-eastern German lowland catchments but can be generalized to the other similar catchments in Australia, North-western Europe and North America.

Acknowledgements We would like to thank the State Agency for Environment, Nature Conservation and Geology (LUNG-MV) and the State office for Agriculture and Environment (StÄLU-MV) MecklenburgVorpommern, Germany for providing the necessary data and help during the water quality measurement campaigns, and also the Universität Rostock for their willingness to finance the publication under the funding program Open Access Publication. The first author gratefully acknowledges an HEC/DAAD scholarship grant in collaboration with the research project BOOT-monitoring in the BMBF program ReWaM (FKZ: 033W039A-F).

Compliance with ethics guidelines Muhammad Waseem, Frauke Kachholz, and Jens Tränckner declare that they have no conflicts of interest or financial conflicts to disclose.

This article does not contain any studies with human or animal subjects performed by any of the authors.

\section{References}

1. Ziemińska-Stolarska A, Skrzypski J. Review of mathematical models of water quality. Ecological Chemistry and Engineering $S$, 2012, 19(2): 197-211

2. Yang Y S, Wang L. A review of modeling tools for implementation of the EU water framework directive in handling diffuse water pollution. Water Resources Management, 2010, 24(9): 1819-1843

3. Arhonditsis G B, Adams-Vanharn B A, Nielsen L, Stow C A, Reckhow K H. Evaluation of the current state of mechanistic aquatic biogeochemical modeling: citation analysis and future perspectives. Environmental Science \& Technology, 2006, 40(21): 6547-6554

4. Loukas A. Surface water quantity and quality assessment in Pinios 
River, Thessaly, Greece. Desalination, 2010, 250(1): 266-273

5. Melidis P, Akratos C S, Tsihrintzis V A, Trikilidou E. Characterization of rain and roof drainage water quality in Xanthi, Greece. Environmental Monitoring and Assessment, 2007, 127(1-3): 15-27

6. Naseem S, Hamza S, Bashir E. Groundwater geochemistry of Winder agricultural farms, Balochistan, Pakistan and assessment for irrigation water quality. European Water, 2010, 31: 21-32

7. Tsakiris G, Alexakis D. Water quality models: an overview. European Water, 2012, 37: 33-46

8. Carpenter S R, Caraco N F, Correll D L, Howarth R W, Sharpley A $\mathrm{N}$, Smith V H. Nonpoint pollution of surface waters with phosphorus and nitrogen. Ecological Applications, 1998, 8(3): $559-568$

9. Vörösmarty C J, McIntyre P B, Gessner M O, Dudgeon D, Prusevich A, Green P, Glidden S, Bunn S E, Sullivan C A, Liermann C R, Davies P M. Global threats to human water security and river biodiversity. Nature, 2010, 467(7315): 555-561

10. EEA (European Environmental Agency). European waters - assessment of status and pressures, EEA Report No. 8/2012. Copenhagen: European Environment Agency, 2012

11. Heinz I, Pulido-Velazquez M, Lund J R, Andreu J. Hydro-economic modeling in river basin management: implications and applications for the European water framework directive. Water Resources Management, 2007, 21(7): 1103-1125

12. Krause S, Jacobs J, Bronstert A. Modeling the impacts of land-use and drainage density on the water balance of a lowland-floodplain landscape in northeast Germany. Ecological Modelling, 2007, 200 (3-4): 475-492

13. Bøgestrand J, Kristensen P, Kronvang B. Source apportionment of nitrogen and phosphorus inputs into the aquatic environment. ResearchGate, 2005

14. Kronvang B, Behrendt H, Andersen H E, Arheimer B, Barr A, Borgvang S A, Bouraoui F, Granlund K, Grizzetti B, Groenendijk P, Schwaiger E, Hejzlar J, Hoffmann L, Johnsson H, Panagopoulos Y, Lo Porto A, Reisser H, Schoumans O, Anthony S, Silgram M, Venohr M, Larsen S E. Ensemble modelling of nutrient loads and nutrient load partitioning in 17 European catchments. Journal of Environmental Monitoring, 2009, 11(3): 572-583

15. Nitrate report. Joint report of the federal ministries for environment, nature conservation, construction and nuclear safety as well as for nutrition and agriculture, 2016 (in German)

16. Trepel M, Palmeri L. Quantifying nitrogen retention in surface flow wetlands for environmental planning at the landscape-scale. Ecological Engineering, 2002, 19(2): 127-140

17. Kieckbusch J J, Schrautzer J. Nitrogen and phosphorus dynamics of a re-wetted shallow-flooded peatland. Science of the Total Environment, 2007, 380(1-3): 3-12

18. Tiemeyer B, Lennartz B, Kahle P. Analysing nitrate losses from an artificially drained lowland catchment (North-eastern Germany) with a mixing model. Agriculture, Ecosystems \& Environment, 2008, 123(1-3): 125-136

19. Krause S, Heathwaite A L, Miller F, Hulme P, Crowe A. Groundwater-dependent wetlands in the UK and Ireland: controls, functioning and assessing the likelihood of damage from human activities. Water Resources Management, 2007, 21(12): 2015-2025

20. Waseem M, Koegst T, Tränckner J. Groundwater contribution to surface water contamination in a North German low land catchment with intensive agricultural land use. Journal of Water Resource and Protection, 2018, 10(3): 231-250

21. Barnwell T O, Johanson R. HSPF: A comprehensive package for simulation of watershed hydrology and water quality. Nonpoint Pollution Control-Tools and Techniques for the Future, Proceedings of a Technical Symposium, 1981, 135-153

22. Munson A D. HSPF modeling of the Charles River Watershed. Dissertation for the Doctoral Degree. Boston: Massachusetts Institute of Technology, 1998

23. EPA (United States Environmental Protection Agency). Water Quality Modeling Basics and Beyond. EPA Website, available on June 24, 2018

24. Crawford N H, Linsley R K. Digital Simulation on Hydrology: Stanford Watershed Model IV. Stanford University Technical Report No. 39, 1966

25. Tzoraki O, Nikolaidis N P. A generalized framework for modeling the hydrologic and biogeochemical response of a Mediterranean temporary river basin. Journal of Hydrology, 2007, 346(3-4): 112121

26. Gallagher M, Doherty J. Parameter estimation and uncertainty analysis for a watershed model. Environmental Modelling \& Software, 2007, 22(7): 1000-1020

27. Ribarova I, Ninov P, Cooper D. Modeling nutrient pollution during a first flood event using HSPF software: Iskar River case study, Bulgaria. Ecological Modelling, 2008, 211(1-2): 241-246

28. Srinivasan R, Ramanarayanan T S, Arnold J G, Bednarz S T. Large area hydrologic modeling and assessment part II: model application 1. Journal of the American Water Resources Association, 1998, 34 (1): 91-101

29. Ficklin D L, Luo Y, Zhang M. Watershed modeling of hydrology and water quality in the Sacramento River watershed, California. Hydrological Processes, 2013, 27(2): 236-250

30. Di Luzio M, Arnold J G, Srinivasan R. Effect of GIS data quality on small watershed stream flow and sediment simulations. Hydrological Processes, 2005, 19(3): 629-650

31. Malagò A, Pagliero L, Bouraoui F, Franchini M. Comparing calibrated parameter sets of the SWAT model for the Scandinavian and Iberian peninsulas. Hydrological Sciences Journal, 2015, 60(5): 949-967

32. Abbaspour K C, Yang J, Maximov I, Siber R, Bogner K, Mieleitner J, Zobrist J, Srinivasan R. Modeling hydrology and water quality in the pre-alpine/alpine Thur watershed using SWAT. Journal of Hydrology, 2007, 333(2-4): 413-430

33. Brown L C, Barnwell T O. The enhanced stream water quality models QUAL2E and QUAL2E-UNCAS: documentation and user manual. Athens: US Environmental Protection Agency, 1987

34. GRASS 4.1. Reference Manual. Champaign: Construction Engineering Research Laboratories, US Army Corps of Engineers, 1993

35. Krysanova V, Hattermann F, Wechsung F. Development of the ecohydrological model SWIM for regional impact studies and vulnerability assessment. Hydrological Processes, 2005, 19(3): 763-783

36. Krysanova V, Wechsung F, Arnold J, Srinivasan R, Williams J. PIK Report Nr. 69, SWIM (soil and water integrated model). User Manual, 2000 
37. DHI. MIKE SHE User Manual Voume 1: User Guide. Denmark: Danish Hydraulic Institute, 2007

38. Dhami B S, Pandey A. Comparative review of recently developed hydrologic models. Journal of Indian Water Resources Society, 2013, 33(3): 34-42

39. Refsgaard J C. Parameterisation, calibration and validation of distributed hydrological models. Journal of Hydrology, 1997, 198 (1-4): 69-97

40. Butts M B, Payne J T, Kristensen M, Madsen H. An evaluation of the impact of model structure on hydrological modeling uncertainty for stream flow simulation. Journal of Hydrology, 2004, 298(1-4): 242-266

41. Gao L, Li D. A review of hydrological/water-quality models. Frontiers of Agricultural Science and Engineering, 2014, 1(4): $267-$ 276

42. Coe M T. Modeling terrestrial hydrological systems at the continental scale: testing the accuracy of an atmospheric GCM. Journal of Climate, 2000, 13(4): 686-704

43. Chow V T. Open Channel Hydraulics. New York: McGraw-Hill Book Company, 1973

44. Wallingford H R. ISIS Flow-User Manual. Wiltshire: HR Wallingford and Sir William Halcrow and Partners, Wallingford Software Ltd, 1997

45. DHI. Mike-11: a modelling system for rivers and channels, reference manual. Horsholm, Denmark: DHI-Water and Development, 2003

46. US Army Corps of Engineers. HEC-RAS river analysis system User's Manual. Washington DC, 2010

47. Fluent Incorporated Company. FLUENT 6.3 User's guide. Lebanon, 2006

48. Hydraulics DHI. MIKE 21 and MIKE 3 flow model hydrodynamic and transport module science documentation. Copenhagen, Denmark: DHI Water and Environment, 2009, 3-4

49. Thompson J R. Simulation of wetland water-level manipulation using coupled hydrological/hydraulic modeling. Physical Geography, 2004, 25(1): 39-67

50. Morita M, Yen B C. Modeling of conjunctive two-dimensional surface-three-dimensional subsurface flows. Journal of Hydraulic Engineering, 2002, 128(2): 184-200

51. Borah D K, Bera M. Watershed-scale hydrologic and nonpointsource pollution models: review of mathematical bases. Transactions of the ASAE (American Society of Agricultural Engineers), 2003, 46(6): 1553

52. Melsen L, Teuling A, Torfs P, Zappa M, Mizukami N, Clark M, Uijlenhoet R. Representation of spatial and temporal variability in large-domain hydrological models: case study for a mesoscale preAlpine basin. Hydrology and Earth System Sciences, 2016, 20(6): 2207-2226

53. Cho Y. Development of a watershed modeling selection program and simple equations as an alternative to complex watershed modeling. Dissertation for the Doctoral Degree. Colorado: Color- ado State University, 2013

54. SloanP G, Moore I D. Modeling surface and subsurface storm flow on steeply-sloping forested watersheds. Water Resources Research, 1984, 20(12): 1815-1822

55. Duda P B, Hummel P R, Donigian A S Jr, Imhoff J C. BASINS/ HSPF: model use, calibration, and validation. Transactions of the ASABE, 2012, 55(4): 1523-1547

56. Hattermann F, Conradt T. SWIM Soil and Water Integrated Model. Pik-potsdam website, available on June 24, 2018

57. Arnold J G, Williams J R, Srinivasan R, King K W, Griggs R H. SWAT: soil and water assessment tool. US Department of Agriculture, Agricultural Research Service, Grassland, Soil and Water Research Laboratory, Temple, TX, 494, 1994

58. Priestley C H B, Taylor R J. On the assessment of surface heat flux and evaporation using large-scale parameters. Monthly Weather Review, 1972, 100(2): 81-92

59. Ritchie J T. Model for predicting evaporation from a row crop with incomplete cover. Water Resources Research, 1972, 8(5): 12041213

60. Smedema L K, Rycroft D W. Land Drainage-Planning and Design of Agricultural Drainage Systems. Ithaca, New York: Cornell University Press, 1983

61. U.S. Department of Agriculture. Soil Conservation Service. Hydrology. Section 4, Chapter 19. National Engineering Handbook. USA Government Printing Office, 1983

62. Kristensen K J, Jensen S E. A model for estimating actual evapotranspiration from potential evapotranspiration. Hydrology Research, 1975, 6(3): 170-188

63. Nasr A E, Bruen M, Jordan P, Moles R, Kiely G, Byrne P. Physically-based, distributed, catchment modelling for estimating sediment and phosphorus loads to rivers and lakes: issues of model complexity, spatial and temporal scales and data requirements. In Paper presented at the National Hydrology Seminar 2004: The Water Framework Directive-Monitoring \& Modelling Issues for River Basin Management, November 2004, Tullamore, co. Offaly. Office of Public Works, 2004

64. Vanderkruk K, Owen K, Grace M, Thompson R. Review of existing nutrient, suspended solid and metal models. Scientific review for Victorian Department of Sustainability and Environment: Aquatic nutrients, suspended solids, pollutant movement and wetland ecology, 2010

65. Ward G H, Benaman J. Models for TDML application in Texas watercourses: screening and model review. Center for Research in Water Resources, University of Texas at Austin, 1999

66. Tuo Y, Chiogna G, Disse M. A multi-criteria model selection protocol for practical applications to nutrient transport at the catchment scale. Water, 2015, 7(6): 2851-2880

67. Kauffeldt A, Wetterhall F, Pappenberger F, Salamon P, Thielen J. Technical review of large-scale hydrological models for implementation in operational flood forecasting schemes on continental level. Environmental Modelling \& Software, 2016, 75: 68-76 